\title{
CLIMATE CHANGE: DEBATE AND REALITY
}

DANIEL R. HEADRICK

\section{Abstract}

The debate about climate change has been raging for over 30 years. Is the climate really changing? If it is, are the changes caused by human actions? If they are, can anything be done about it? And, if so, should anything be done? On each of these questions, opinions clash. On one side are those who would say yes to all four questions. Among them are almost all climate scientists, most of the world's governments and a large part of the educated public. On the other side are the current United States Government, most oil, gas and coal corporations, and most conservative politicians and their supporters, especially in the United States.

It cannot be denied that the debate has caused confusion in the mind of the public-at least in the United States-and has helped prevent effective measures to mitigate global warming. In this essay, however, I argue that the impact of the debate pales in comparison to that of two other factors: developmentalism, the glorification of economic growth; and consumerism, the modern energy-intensive way of life. While the causes of the failure to mitigate global warming can be found in every country, the case of China is particularly glaring.

Keywords: China, climate change, developmentalism, US Government

\section{Climate change: The evidence}

Among climate scientists, there is an almost complete consensus on the anthropogenic causes of global warming. All 928 articles on the subject published in refereed scientific journals between 1993 and 2003 agree on this point, as do the reports of the United Nations' Intergovernmental Panel on Climate Change (IPCC), the National Academy of Science, the American Meteorological Society, the American Geophysical Union and the American Association for the Advancement of Science. An analysis of 1,372 climate researchers and their publications showed that '(i) $97-98 \%$ of the climate researchers most actively published in the field ... support the tenets of ACC [anthropogenic climate change] outlined by the 
Intergovernmental Panel on Climate Change, and (ii) the relative climate expertise and scientific prominence of the researchers unconvinced of ACC are substantially below that of the convinced researchers.'

Concerns about anthropogenic climate change-especially regional desiccation caused by deforestation - date back to the eighteenth century and earlier. In the 1970 s and 1980s, scientists began worrying about global warming. In response to increasing scientific evidence, the UN established an IPCC in 1988. This organisation was charged with analysing all the relevant scientific literature and issuing periodic Assessment Reports. Its first Assessment Report, issued in 1990, was followed by reports in 1995, 2001, 2007 and 2014. These reports attributed climate change and its associated climate anomalies (droughts, floods, hurricanes and severe storms) to the increasing proportion of greenhouse gases (carbon dioxide and methane) in the atmosphere since the Industrial Revolution, and especially since the Second World War. The IPCC reports present not only a consensus of climate scientists, but also a 'Summary for Policymakers' to advise governments on ways to slow down global warming and mitigate its impact. Each report showed that climate change was happening faster and that its effects were more powerful than had been described in the preceding reports.

Scientists have identified several causes of global warming. The most important is the rising proportion of carbon dioxide $\left(\mathrm{CO}_{2}\right)$ in the atmosphere produced by the great increases in the human population and in the world economy. From 800,000 to 10,000 years ago, $\mathrm{CO}_{2}$ fluctuated between 200 and 300 parts per million (ppm), in rhythm with global temperatures and sea levels. From then until the late nineteenth century, it ranged from 275 to $285 \mathrm{ppm}$. Then it began to rise. In 1900 it reached $297 \mathrm{ppm}$. In 1958, it stood at $315 \mathrm{ppm}$. By 1995 it had risen to $360 \mathrm{ppm}$, and by 2005 to 378. In August 2018 it reached 406.84 ppm, a proportion not seen since 3 million years ago. ${ }^{2}$ Not only has this proportion grown, its rate of increase has risen as well, from $1 \mathrm{ppm}$ per year in the $1950 \mathrm{~s}$ to $2-2.5 \mathrm{ppm}$ per year in the early 2000s. The consequence is not just that the Earth is getting warmer, but that it is doing so faster than ever before. ${ }^{3}$

1 William R. L. Anderegg et al., 'Expert Credibility in Climate Change', Proceedings of the National Academy of Sciences 107, no. 27 (1 June 2010): 12107-9. See also Naomi Oreskes, 'The Scientific Consensus on Climate', Science 306, no. 5702 (3 December 2004): 1686; Elizabeth Kolbert, 'Rethinking How We Think About Climate Change', Audubon (September-October 2014): 48; and William R. Ruddiman, Earth's Climate, Past and Future (New York: W. H. Freeman, 2008), 341.

2 National Oceanic and Atmospheric Administration, Earth System Research Laboratory, Global Monitoring Division, 'Trends in Atmospheric Carbon Dioxide', esrl.noaa.gov, accessed August 2018.

3 John R. McNeill and Peter Engelke, The Great Acceleration: An Environmental History of the Anthropocene since 1945 (Cambridge, MA: Harvard University Press, 2016), 64-9; Elizabeth Kolbert, Field Notes from a Catastrophe: Man, Nature, and Climate Change (New York: Bloomsbury, 2009), 43-4; Wolfgang Behringer, A Cultural History of Climate, translated by Patrick Camiller (Cambridge: Polity Press, 2010), 183-4; Henry Pollack, $A$ World Without Ice (New York: Penguin, 2010), 183-7; John Carey, 'Global Warming: Faster than Expected?', Scientific American (November 2012): 51-5; 'Greenhouse Gas to Reach 3-Million-Year High', livescience.com, accessed 6 June 2013. 
Since 1900, the main source has been the burning of fossil fuels, at first mostly coal but increasingly oil and natural gas. Since 2000, global emissions of greenhouse gases have been growing by 3 per cent per year. In 2012, burning fossil fuels produced 35.6 billion tons of $\mathrm{CO}_{2}, 58$ per cent more than in 1990; another 3 billion tons came from deforestation, mainly in the tropics. The United States was long the world's foremost source of carbon emissions, with 28.5 per cent of the world's total between 1850 and 2008, but it has recently been overtaken by China, with 23.6 per cent of global emissions in $2009 .{ }^{4}$

$\mathrm{CO}_{2}$ is not the only gas that prevents infrared rays from escaping, trapping heat in the atmosphere as if in a greenhouse. Methane $\left(\mathrm{CH}_{4}\right)$, emitted by livestock flatulence, by decaying vegetation in rice paddies, wetlands and peat bogs, by melting permafrost and from oil wells, accounts for 16 per cent of the greenhouse effect; its proportion of the atmosphere has risen from 350-700 parts per billion before industrialisation to 1,750 parts per billion today. Nitrous oxide $\left(\mathrm{N}_{2} \mathrm{O}\right)$ is a byproduct of agricultural fertilisers, livestock and burning fossil fuels, as well as coming from natural sources such as tropical soils; its proportion has reached 310 parts per trillion.

The main cause of the increase in the proportion of greenhouse gases in the atmosphere is the ever-growing human demand for energy. The astonishing growth of the human population and of the global economy, and the rising standards of living over the past half century, were accompanied by a proportional growth in primary energy consumption. ${ }^{5}$ Between 1965 and 2015, primary energy consumption grew from 3,731 million metric tons of oil equivalent (a standard measure of energy consumption) to 13,105 million metric tons, an increase of 350 per cent. During that period, oil consumption increased by 280 per cent, natural gas consumption by 540 per cent and coal consumption from by 270 per cent. In 2015, 78.4 per cent of that energy came from fossil fuels (oil, coal and natural gas); another 3.6 per cent from hydro; 2.3 per cent from nuclear; 9.1 per cent from traditional biomass (mainly firewood); and 5.8 per cent from modern renewable sources: solar panels, ethanol, biodiesel, wind and geothermal. ${ }^{6}$ Coal production, once surpassed by oil as the source of most of the $\mathrm{CO}_{2}$ being emitted, has been rising again, especially in developing countries; from 1965 to 2011, the use of coal has increased sevenfold in Brazil and India, 13-fold in Mexico, and 15-fold in South Korea and China. ${ }^{7}$

\footnotetext{
4 Mike Orcutt, 'The Enduring Technology of Coal', Technology Review 116, no. 3 (May-June 2013): 15; Michael Le Page and Michael Slezak, 'No Sign of Emissions Letting Up as Climate Talks Begin', New Scientist, 8 December 2012, 11; Clive Hamilton, Requiem for a Species: Why We Resist the Truth about Climate Change (London and Washington, DC: Earthscan, 2010), 5; Ruddiman, Earth's Climate, 328.

5 BP Statistical Review of World Energy June 2017, bp.com, accessed August 2018. See also International Energy Agency, Key World Energy Statistics, iea.org, accessed February 2018. The IEA, representing the major countries of the world, is affiliated with the Organisation for Economic Co-operation and Development.

6 REN21.2017: Renewable Energy Policy Network for the 21st Century, 'Annual Report 2017', ren21.net, accessed February 2018.

7 'The Enduring Technology of Coal', 15.
} 


\section{Climate change believers}

The reports of the IPCC, and especially their predictions of future problems if measures are not taken to reduce greenhouse gas emissions, have led some pundits to issue dire prophecies of doom, predicting that global warming will lead to wars, millions of deaths, an economic depression and massive flights of refugees. ${ }^{8}$ Thus in 2006, James Lovelock, author of The Revenge of Gaia, wrote: 'Despite all our efforts to retreat sustainably, we may be unable to prevent a global decline into a chaotic world ruled by brutal war lords on a devastated Earth." According to the Australian philosopher and public intellectual Clive Hamilton, 'The kind of climate that has allowed civilization to flourish will be gone and humans will enter a long struggle just to survive'. ${ }^{10}$ Slightly less apocalyptic is the conclusion reached by Donella Meadows et al. in a revised edition of The Limits to Growth: 'We worry that current policies will produce overshoot and collapse. ${ }^{11}$ Of course, such doomsayers do not represent the consensus of opinion among climate change believers. Yet the predictions of climate scientists that the Earth will become warmer have, through a process of epistemological slippage, morphed, in the minds of believers, into an expectation of hard times ahead, if not for all humankind, then at least for the poor and those who live near the sea, an expectation based on what the scholar of climate change Mike Hulme calls 'the West's loss of confidence in the future'. ${ }^{12}$

Worries about climate change and the future are not limited to Western pundits and pessimists. The increasing scientific attention and the dire predictions contained in the IPCC Assessment Reports have also aroused the attention of the international community. The first IPCC Assessment Report led the UN to call a Conference on Environment and Development in June 1992 in Rio de Janeiro. It was attended by delegates of over 170 nations, over 100 of them represented by their heads of government or heads of state, as well as thousands of activists, representatives of environmental non-government organisations (NGOs) and women's organisations, business leaders, religious figures and journalists. It was the largest international conference in history. ${ }^{13}$

\footnotetext{
8 Mike Hulme, 'Reducing the Future to Climate: A Story of Climate Determinism and Reductionism', Osiris 26 (2011): 247, doi.org/10.1086/661274.

9 James Lovelock, The Revenge of Gaia: Why the Earth Is Fighting Back (London: Allan Lane, 2006), quoted in Hulme, 'Reducing the Future to Climate', 198.

10 Hamilton, Requiem for a Species, 14.

11 Donella Meadows et al., The Limits to Growth: The Thirty-year Update (London: Earthscan, 2004), quoted in Mike Hulme, Why We Disagree About Climate Change: Understanding Controversy, Inaction and Opportunity (Cambridge: Cambridge University Press, 2009), 260.

12 Hulme, 'Reducing the Future to Climate', 266.

13 Different sources give somewhat different numbers: 'Earth Summit', in Wikipedia (accessed April 2014) gives 172 government and 108 heads of state or of government; Behringer, A Cultural History of Climate, 192, puts the number at 178 countries; Daniel Yergin, The Quest: Energy, Security, and the Remaking of the Modern World (New York: Penguin, 2017), 472, mentions 160 heads of state, government and international organisations. On the international politics of global warming, see McNeill and Engelke, The Great Acceleration, 76-82. See also Ramachandra Guha, Environmentalism: A Global History (New York: Longman, 2000), 141.
} 
Climate change dominated the proceedings of that conference and the media reports. On that subject, the world's nations were split into factions. The delegates of the poorer countries pointed out that 80 per cent of the world's resources were consumed by 20 per cent of its people living in the industrialised world. They contrasted the 'luxury emissions' produced by the gas-guzzling automobiles of the rich with the 'survival emissions' of the poor. The developing nations' delegates, led by China and India, saw restrictions on greenhouse gas emissions as an obstacle to their development and asked why they should pay for the sins of the rich countries. The European nations were eager to set targets and timetables for greenhouse gas reductions, but the United States was opposed. President George H. W. Bush, under pressure from the fossil fuel industries, instructed the American delegation to dilute or block most diplomatic initiatives. The document that concluded the conference, known as the UN Framework Convention on Climate Change, was signed by 154 nations, including the United States. Under the terms of that agreement, which was not legally binding, the rich countries pledged to reduce their greenhouse gas emissions to the 1990 level by the year 2000, a wildly optimistic promise. Developing countries agreed only to monitor their emissions. ${ }^{14}$

The next major international conference, held in Kyoto in 1997, was called in response to the IPCC's Second Assessment Report of 1996. Unlike the Rio conference, where the participants made promises they could not keep, the goals of the Kyoto conference were to agree on binding targets for greenhouse gas emissions and devise mechanisms to implement them. Developing countries, led by India, China and Brazil, refused to accept binding commitments because they were about to embark on a period of extraordinary economic growth. They blamed the rich countries for having caused global warming by burning coal and oil, and proposed that the rich should be the first to take legally binding steps to reduce their emissions. ${ }^{15}$ As at Rio, the United States insisted that all countries should share the burden of reducing emissions, especially since the larger Third World countries were expected to produce more emissions than the rich countries within the next 20 years.

The result of the conference, called the Kyoto Protocol, was a very watered-down version of the expectations of the organisers and the scientists of the IPCC. China and India accepted no restrictions of their emissions. Australia and Saudi Arabia expressed reservations. The European Union agreed to reduce its emissions by 8 per cent, the United States by 7 per cent, and Japan and Canada by 6 per cent.

14 Yergin, The Quest, 468-73; 'United Nations Framework Convention on Climate Change', in Wikipedia, accessed July 2013; Tim Flannery, The Weather Makers: How Man Is Changing the Climate and What It Means for Life on Earth (New York: Grove Press, 2005), 223, 243; Benjamin Kline, First Along the River: A Brief History of the U.S. Environmental Movement (Lanham, MD: Rowman and Littlefield, 2007), 110-13; Hamilton, Requiem for a Species, 98.

15 William K. Stevens, 'Greenhouse Gas Issue: Haggling over Fairness', New York Times, 30 November 1997; Yergin, The Quest, 485-95, 512-13; 'Kyoto Protocol', in Wikipedia, accessed April 2014. 
Although US President Bill Clinton signed the Kyoto Protocol, neither he nor his successor George W. Bush ever submitted it to the Senate. In short, the Kyoto Protocol was an expression of good intentions, but little else. ${ }^{16}$

Meanwhile, global carbon emissions, far from declining to 1990 levels, rose from 6 gigatons in 1990 to 8.5 gigatons in 2007, a 40 per cent increase, exceeding the IPCC's worst-case scenario. ${ }^{17}$ As the scientific prognosis grew darker and public concerns mounted, the governments of the world responded with ever more frequent conferences. In December 2009, a third major international conference was held in Copenhagen, attended by delegates of 193 nations. Of the 193 nations that attended, 138 signed or pledged to sign a non-binding agreement, but no treaty was forthcoming. ${ }^{18}$

A year later, another conference, this one at Cancún, Mexico, achieved a more positive result, namely a pledge to prevent average global temperatures from rising more than $2^{\circ} \mathrm{C}\left(3.6^{\circ} \mathrm{F}\right)$ above pre-industrial levels. But it did not require that the signatory nations adopt the technological or economic changes that scientists felt necessary to avoid dangerous climate change. ${ }^{19}$

Most recently, the 2015 UN Climate Change Conference in Paris aimed to limit global warming to $2^{\circ} \mathrm{C}$ or less, compared to pre-industrial levels, by cutting greenhouse gas emissions to zero in the second half of the twenty-first century. Most of the governments represented at the conference accepted this goal in principle. However, since there is no binding enforcement mechanism, its implementation is far from certain. Compromising this agreement is the dramatic drop in fossil fuel prices, triggering a rise in consumption, hence emissions.

\section{Global warming deniers}

Opposed to the IPCC and the believers are the deniers, or, as they prefer to call themselves, the sceptics. Some agree that global warming is real, but claim it is a natural phenomenon in which humans have played no part; S. Fred Singer and Dennis T. Avery's Unstoppable Global Warming: Every 1,500 Years is an example

16 Flannery, The Weather Makers, 223-31; Kolbert, Field Notes from a Catastrophe, 197; Yergin, The Quest, 489-99; Kline, First Along the River, 135-6, 150-72; Behringer, A Cultural History of Climate, 192-5; Stevens, 'Greenhouse Gas Issue'.

17 Flannery, The Weather Makers, 243; Behringer, A Cultural History of Climate, 192-5; Kolbert, Field Notes from a Catastrophe, 15-72, 197; Hamilton, Requiem for a Species, 98; 'Earth Summit' and 'United Nations Framework Convention on Climate Change', in Wikipedia, accessed July 2013.

18 '2009 United Nations Climate Change Conference' (also known as the 'Copenhagen Summit') in Wikipedia, accessed July 2013; Robert Marks, China: Its Environment and History (Lantham, MD: Rowman and Littlefield, 2012), 316; Yergin, The Quest, 515.

19 '2010 United Nations Climate Change Conference' (also known as the 'Cancún Summit') in Wikipedia, accessed July 2013. 
of this genre. ${ }^{20}$ Then there is a large and growing literature that claims that global warming is an elaborate hoax fomented by a cabal of scientists and leftists, with titles such as Red Hot Lies: How Global Warming Alarmists Use Threats, Fraud, and Deception to Keep you Misinformed; Power Grab: How Obama's Green Policies Will Steal Your Freedom and Bankrupt America; Eco-Tyranny: How the Left's Green Agenda Will Dismantle America; and The Real Global Warming Disaster: Is the Obsession with 'Climate Change' Turning Out to Be the Most Costly Scientific Blunder in History?21

In the United States, global warming denial is more than a literary genre; it is a political stance, with Democrats generally claiming concern for the environment and Republicans reflecting the interests of the fossil fuel industries. Under the administrations of Ronald Reagan, George H. W. Bush and George W. Bush, scientists working for the Environmental Protection Agency and the National Oceanic and Atmospheric Administration complained that their work was interfered with and their reports altered by politically appointed administrators. ${ }^{22}$ During the 2011 presidential campaign, Republican candidates Ron Paul and Rick Perry called climate change 'a hoax', while front runner Mitt Romney said: 'My view is that we don't know what's causing climate change on this planet and the idea of spending trillions and trillions of dollars to try and reduce $\mathrm{CO}_{2}$ emissions is not the right cause for us. ${ }^{23}$ That year, the US House of Representatives defeated the proposed amendment that stated: 'Climate change is occurring, is largely caused by human activities, and poses significant risks for public health and welfare. ${ }^{24}$

In 2017, President Donald Trump withdrew the United States from the Paris Agreement, to the dismay of the European Union and even China, which had belatedly taken a leadership role in climate awareness.

In climate politics, as in all other areas of politics, important economic interests were at play. And these interests influenced politicians through well-funded lobbies. As early as the 1980s, Peabody Energy, the world's largest coal company,

20 S. Fred Singer and Dennis T. Avery's Unstoppable Global Warming: Every 1,500 Years (Lanham, MD: Rowman \& Littlefield, 2007).

21 Christopher C. Horner, Red Hot Lies: How Global Warming Alarmists Use Threats, Fraud, and Deception to Keep You Misinformed (Washington, DC: Regnery, 2008), and Power Grab: How Obama's Green Policies Will Steal Your Freedom and Bankrupt America (Washington, DC: Regnery, 2010); Brian Sussman, Eco-Tyranny: How the Left's Green Agenda Will Dismantle America (Washington, DC: WND Books, 2012); and Christopher Booker, The Real Global Warming Disaster: Is the Obsession with 'Climate Change' Turning Out to Be the Most Costly Scientific Blunder in History? (London: Continuum, 2010).

22 Joshua B. Howe, Behind the Curve: Science and the Politics of Global Warming (Seattle, WA: University of Washington Press, 2004), 118-46, 170-96; Naomi Oreskes and Erik M. Conway, Merchants of Doubt: How a Handful of Scientists Obscured the Truth on Issues from Tobacco Smoke to Global Warming (London: Bloomsbury Press, 2011), 183-215.

23 Shawn Lawrence Otto, 'America’s Science Problem', Scientific American (November 2012): 65, doi.org/10.1038/ scientificamerican1112-62; Oreskes, 'The Scientific Consensus', 1686; 'Climate of Distrust' (editorial), Nature 436(7047): 1; Flannery, The Weather Makers, 241.

24 Geoffrey Parker, The Global Crisis: War, Climate, and Catastrophe in the Seventeenth-Century World (New Haven, CT: Yale University Press, 2013), 687. 
backed the production of the video 'The Greening of Planet Earth' that claimed that $\mathrm{CO}_{2}$ would raise agricultural yields, thereby ending world hunger. The Exxon Mobil Corporation and other fossil fuel companies funded several Washington think tanks, such as the George C. Marshall Institute. Coal, oil, gas, chemical and automobile companies financed the Global Climate Coalition, the Climate Action Partnership, the Heritage Foundation, the Competitive Enterprise Institute and other think tanks, as well as fake citizens action groups, such as the Advancement of Sound Science Coalition. What these lobbyists have achieved is to make people believe that scientists disagree about global warming (when they do not), leaving the public confused. ${ }^{25}$

By 2006, most fossil fuel companies had stopped denying the existence of global warming, but argued instead that there was no hurry, and no changes would be needed for another 20 years. The spokesman, Patrick Michaels, a senior research fellow at the libertarian Cato Institute, admitted that 'human-induced climate change is indeed real, but that this will not lead to an environmental apocalypse' and 'there is plenty of time- a century or so-for technological development that will be more efficient and emit far less carbon dioxide. ${ }^{26}$

By lobbying against climate science and supporting conservative candidates, these companies succeeded in postponing any meaningful action and casting the United States in the role of obfuscator at international conferences. In the words of the Australian environmental scientist Tim Flannery: 'It is almost impossible to overestimate the role these [American energy] industries have played over the past two decades in preventing the world from taking serious action to combat climate change. ${ }^{27}$

There is no question that the major corporations-especially the fossil fuel producers-are responsible for encouraging the emission of greenhouse gases, both directly by the public through sales of gasoline, diesel fuel and natural gas, and indirectly through the production of electricity, cement and energy-intensive manufacturing, and the sale of houses, motor vehicles and appliances. Their lobbying and their publicity campaigns, and that of the think tanks that they sponsored, have contributed to the doubts in the mind of the public.

Think tanks, lobbyists, conservative media and politicians influence public opinion, but only in the direction in which the public is leaning anyway. In the United States, that direction has been toward increasing scepticism. A poll taken in 2006 showed

25 Dale Jamieson, Reason in a Dark Time (New York: Oxford University Press, 2014), 81-96; Kolbert, 'Rethinking', 46-8; Oreskes and Conway, Merchants of Doubt, 186-90, 213.

26 Patrick Michaels and Robert C. Balling, Jr, Climate of Extremes: Global Warming Science They Don't Want You to Know (Washington, DC: Cato Institute, 2009), 7; see also Michaels's Meltdown: The Predictable Distortion of Global Warming by Scientists, Politicians, and the Media (Washington, DC: Cato Institute, 2004).

27 Flannery, The Weather Makers, 240. See also 'Climate Skeptic Group Works to Reverse Renewable Energy Mandates', Washington Post, 24 November 2012; Hamilton, Requiem for a Species, 100-6. 
that 92 per cent of Americans had heard of global warming, 90 per cent believed that the United States should reduce greenhouse gas emissions, and 70 per cent believed that it should do so regardless of what other nations did. In April 2008, only 71 per cent of Americans believed there was solid evidence of global warming and 47 per cent believed it was due to human activities. And by October 2009, only 57 per cent believed in global warming and 36 per cent blamed it on humans. When asked whether global warming was a serious problem, in 200844 per cent of the people interviewed agreed that it was, but by 2009, only 35 per cent did so, and Americans ranked global warming as last in a list of 20 priorities. In other words, they were experiencing global-warming fatigue. ${ }^{28}$

As American politics have become more polarised, so have Americans' views on global warming. In 1997, there were only slight differences between Republicans and Democrats on the subject, with 48 per cent of Republicans and 52 per cent of Democrats expressing concern. By 2008, however, the gap had grown by 34 percentage points, with 42 per cent of Republicans and 76 per cent of Democrats expressing concern. ${ }^{29}$

\section{Obstacles to mitigation}

The influence of corporate lobbies and the election of climate change-denying politicians, important though they are, cannot alone explain the weakness of the measures taken so far to counter global warming. Two other obstaclesdevelopmentalism and consumerism—stand in the way of effective actions.

\section{Developmentalism}

Developmentalism is an ideology that reflects both the goals of economic development and the means to achieve them. ${ }^{30}$ Since the 1930 s, nations have used the gross domestic product (GDP) — the value of all goods and services expressed in monetary terms - as the measure of the size of their economies and its rate of growth. For economists, the oceans, the air, the wilderness and other non-human parts of the biosphere are 'externalities'. They discount all values that cannot be expressed monetarily, such as air and water quality, public health, the lives of plants and animals, and the aesthetic and spiritual benefits of nature. Politicians, the press and the public celebrate the growth of GDP and deplore a stagnant economy or a recession.

28 Pew Research Center, 'Fewer Americans See Solid Evidence of Global Warming' (22 October 2009), www. people-press.org/2009/10/22/fewer-americans-see-solid-evidence-of-global-warming, accessed September 2018; Pollack, A World Without Ice, 152; Hamilton, Requiem for a Species, 120-3.

29 Clive Hamilton, Earthmasters: The Dawn of the Age of Climate Engineering (New Haven, CT: Yale University Press, 2013), 86.

30 I owe the concept of developmentalism to Robert Marks, China, 71. 
The imperative to produce more and maximise a nation's economic growth has become ingrained in the ideologies of all political parties. Politicians of all stripes justify economic development on nationalist grounds-to make their nation stronger or more prosperous. International organisations like the World Bank, the International Monetary Fund and the UN Environment Programme also see development as an unalloyed good. Even economists, with very few exceptions, believe that growth is a good thing, and always will be. ${ }^{31}$ As the environmental historian John McNeill noted: 'The overarching priority of economic growth was easily the most important idea of the twentieth century. ${ }^{32}$

The environment, meanwhile, is easily ignored. The exploitation of natural resources is taken for granted; substitutes are sought for those in short supply. Nations desperate to develop their military or to alleviate poverty feel they can ill afford to jeopardise their economic growth for the sake of the natural environment. In democracies, popular opinion gives the highest priority to providing jobs; only in the last decades of the twentieth century has protecting the environment appeared on the list of priorities.

\section{Consumerism}

Businesses and governments are not the only ones to blame for the lack of progress in reducing greenhouse gas emissions, consumers are also. There are two reasons for this response. One is biology, for humans evolved in a tropical African environment. Most people who live in the temperate zone prefer warm weather to cold, and spring and summer to autumn and winter. Many take winter holidays in warmer places, and many others move to warmer regions when they retire. Some even welcome a warmer climate.

The other reason is what was once called the American way of life. The US economy is based on the mass consumption of comfortable housing, automobiles, appliances, frequent travel and other amenities. As one salesman wrote in 1955:

Our enormously productive economy demands that we make consumption our way of life, that we convert the buying and use of goods into rituals, that we seek our spiritual satisfactions, our ego satisfaction, in consumption ... We need things consumed, burned, worn out, replaced, and discarded at an ever increasing rate. ${ }^{33}$

31 Or, as Kenneth Boulding put it: 'Anyone who believes exponential growth can go on forever in a finite world is either a madman or an economist': 'The Economics of the Coming Spaceship Earth', in Radical Political Economy: Exploration in Alternative Economic Analysis, ed. Victor D. Lippit (Armonk, NY: M. E. Sharpe, 1996), 362. Among the few economists who question the idea of infinite growth is Herman E. Daly, see his 'Economics in a Full World', Scientific American (September 2005): 100-7, and Beyond Growth: The Economics of Sustainable Development (Boston, MA: Beacon Press, 1996).

32 John R. McNeill, Something New Under the Sun: An Environmental History of the 20th-Century World (New York: Norton, 2000), 336.

33 Victor Lebow, 'Price Competition in 1955', Journal of Retailing (Spring 1955), quoted in Simon L. Lewis and Mark A. Maslin, The Human Planet: How We Created the Anthropocene (London: Penguin Books, 2018), 226. 
The American way of life is based on cheap energy. As Ari Fleischer, Press Secretary for President George W. Bush, put it: 'The President believes that [energy use is] an American way of life and that it should be the goal of policymakers to protect the American way of life. The American way of life is a blessed one. ${ }^{34}$ In a society in which people are judged by their consumption of goods and services, and in which such consumption correlates closely with the consumption of fossil fuels, reducing one's carbon footprint is equated with reducing one's standard of living. After the Second World War, the American way of life spread to Europe and, more recently, to East Asia and other parts of the world. For a global middle class, a standard of living based on an increasing consumption of energy is not just a question of comfort, but even one of identity.

\section{Electricity}

The two elements of modern economies that consume the most energy are electricity and motor vehicles. Once consumers have access to these two aspects of modern life, it is hard to imagine living without them.

In recent decades, the world's production of electricity has increased from 6,298 terawatt hours (TWh) in 1974 to 25,082 TWh in 2016, an average rate of growth of 3.3 per cent per year. Of the amount produced in 2016, 38.3 per cent came from burning coal, 23.1 per cent from natural gas and 3.7 per cent from oil; in other words, 65.1 per cent came from burning fossil fuels that emit greenhouse gases. Of that electricity, 31.9 per cent was used by industry, 31.1 per cent by private residences and 31.8 per cent by commercial and public activities. Much of the growth in the consumption of electricity can be attributed to its spread to the nonWestern world, especially-as we shall see-to China. ${ }^{35}$

Much has been made of the astonishing rise in renewable energy sources, especially photovoltaic solar panels and wind farms. In many places, the cost of electricity from these sources has dropped to the point where it is competitive with electricity from fossil fuel-burning power plants. Between 2010 and 2016, the cost of solar energy dropped by 70 per cent and that of wind energy by 25 per cent, while the cost of battery storage (essential to even out the fluctuations in sunlight and wind) fell by 40 per cent. ${ }^{36}$ Gains in the efficiency of generation and transmission of electricity and of electric appliances show significant promise. Wind farms, photovoltaic solar

34 Hamilton, Requiem for a Species, 34.

35 International Energy Agency, Electricity Information Overview, iea.org, accessed August 2018. See also US

Energy Information Administration, eia Beta, eia.gov, accessed August 2018.

36 International Energy Agency, World Energy Outlook 2017: Executive Summary, iea.org, accessed February 2018. 
panels and hydroelectric power plants produce little or no greenhouse gas. In the future, they will replace oil- and gas-fired plants, but too slowly to reverse global warming. Meanwhile, the use of coal shows no signs of diminishing. ${ }^{37}$

\section{Motor vehicles}

Most of the good news about reducing greenhouse gas emissions comes from the power generation sector. In the transport sector, attempts to reduce emissions are losing the battle against the proliferation of motor vehicles and the infrastructures that support them. In the past half-century, world motor vehicle production has simply exploded, from 16.5 million vehicles in 1960 to 94.9 million in 2016, an almost sixfold increase. As a result of this boom, global motor vehicle registrations reached 1.3 billion in 2016 and are expected to reach 2 billion by $2040 .{ }^{38}$

One of the key factors that determine the kinds of vehicles that consumers buy is the price of fuel. As every driver knows, the price of gasoline fluctuates wildly, rising during oil crises and dropping in the ensuing gluts. Thus, the average price of regular gasoline in the United States peaked at $\$ 4.12$ a gallon in June 2008 and again at $\$ 4.10$ in May 2011, only to drop to $\$ 1.70$ in January 2015; in real terms, these prices were among the lowest since the early 1970s. The prices of diesel and other petroleum fuels have followed the same trends.

In recent years, North American consumers have increasingly shifted their demand from passenger cars to sport utility vehicles (SUVs), crossovers (small SUVs) and pickup trucks; they now account for over half of US sales. In December 2017, of the 722,822 vehicles sold by the big three Detroit automobile manufacturers, 82 per cent were pickups, SUVs or minivans; only 18 per cent were passenger cars. ${ }^{39}$ Part of the reason is rising incomes and falling fuel prices, but another is deliberate government policy. In response to the fuel crises and the environmental movement of the 1970s, the US Government imposed tight restrictions on the fuel economy and emissions of passenger cars, but exempted truck-like vehicles. Automobile manufacturers responded by building SUVs, vans and pickup trucks with all the amenities of passenger cars. Because such vehicles consume more fuel and are less likely to be replaced by electric vehicles than are saloon cars, these shifts in consumer tastes and government policies have been roadblocks to stabilising emissions.

37 Eduardo Porter, 'Wind and Solar Power Advance, but Carbon Refuses to Retreat', New York Times, 7 November 2017); 'Carbon Emissions Set to Rise', Nature 551(7680): 277.

38 International Energy Agency, World Energy Outlook 2017: Executive Summary; Organisation Internationale des Constructeurs d'Automobiles, 2016 Production Statistics, oica.net, accessed February 2018.

39 Consumer Reports, April 2018, 16. 
The price of motor fuels in other countries has followed a similar pattern, but at different levels, due to taxes. Thus, in February 2018, when the average price of gasoline was $\$ 2.88$ per gallon in the United States, it was $\$ 4.46$ in China and $\$ 4.95$ in Japan. It was much higher in Europe: \$6.38 in Germany, \$6.40 in the UK and \$6.99 in France. ${ }^{40}$ Despite higher fuel prices, other countries' consumers have followed in the footsteps of Americans. In 2017, over a third of passenger vehicles sold worldwide were SUVs or crossovers. In Europe, long the land of small economy cars, sales of SUVs have doubled in the past five years. In China, SUVs are particularly popular, and it is expected that they will represent half of all passenger vehicles sold by $2022 .{ }^{41}$

By then, won't cars be electric? Indeed, the number of electric (including plug-in hybrid) vehicles has risen dramatically in recent years, from near zero in 2000 to 2 million (or 0.14 per cent of all motor vehicles) in 2016, and is expected to reach 280 million (or 14 per cent) in 2040. In relative terms, that is an encouraging sign. But in absolute terms, it means that the number of non-electric (i.e. petroleumburning) vehicles will also grow, reaching 1.72 billion in 2040, and will contribute much more to greenhouse gas emissions than the electric vehicles can mitigate. ${ }^{42}$ Furthermore, electric vehicles are not without environmental costs, for they require electricity, much of which will in the future be produced by burning fossil fuels.

\section{Soft denial}

Even people who recognise that climate change is real and is the result of human actions are poorly motivated to change their consumption habits. They may agree with the scientific consensus, yet they behave as if they agreed with the climatechange deniers; one could call their response to global warming 'soft denial'. This attitude of 'soft denial' is not a matter of ignorance. As the sociologist Kari Norgaard found, 'Respondents who are better informed about climate change feel less rather than more responsible for it ... People stopped paying attention to global climate change when they realized that there is no easy solution for it'. ${ }^{43}$

One major obstacle to changing consumer habits lies in the disparity between costs and benefits. As consumption takes place in the present, reducing one's consumption would have an immediate impact on one's lifestyle. The benefit thereof, namely a reduction in climate change, would be spread over large areas, perhaps the entire world; furthermore, they would not be felt for many years, perhaps centuries.

\footnotetext{
40 For US prices, see gasbuddy.com; for international comparisons, see globalpetrolprices.com, accessed February 2018.

41 Neal E. Boudette, 'More Luxury Buyers Ditch the Imports and Pick up a Truck', New York Times, 15 February 2018; Hiroko Tabuchi, 'The World Is Embracing S.U.V.s. That's Bad News for the Climate', New York Times, 3 March, 2018.

42 International Energy Agency, World Energy Outlook 2017: Executive Summary.

43 Kari Marie Norgaard, Living in Denial: Climate Change, Emotions, and Everyday Life (Cambridge, MA: MIT Press, 2011), 2, doi.org/10.7551/mitpress/9780262015448.001.0001.
} 
Another obstacle is what economists call discounting the future. Weighing the impact of current consumption on future generations is an ethical and psychological problem. Most people love their children, and their grandchildren if they have any, and worry about the climate they will have to contend with. But few people take into account the fate of their great-grandchildren and beyond. Hence the trade-off between giving up current consumption and benefiting future generations is a difficult one for most people to accept. ${ }^{44}$

Another factor contributes to the difficulty, namely the expectation of future economic growth. The world economy has been growing for so many centuries (albeit with many ups and downs) that it is natural to assume that it will continue growing in the future. Even the IPCC assumes future growth of 2.3 to 3.6 per cent per annum. Extrapolating into the future, that means that the Gross World Product in 2050 will be up to six times larger than it is today. ${ }^{45}$ Whether the beneficiaries of this economic growth will be more willing to trade off the consumption of material goods and services for environmental or aesthetic benefits than wealthy people today is questionable.

Finally, there are those, like Michaels quoted above, who believe that future technologies can save the planet from the damage caused by past technologies. Some new technologies already exist that contribute much less to global warming than the ones they replace: wind farms, solar panels and electric vehicles come to mind. Others-geo-engineering, carbon capture and storage, solar radiation management—are still pie in the sky, with unpredictable side effects. ${ }^{46}$

Thus human nature, mass consumption, cost-benefit analysis, discounting the future, and expectations of economic growth and of technological fixes all contribute to the lethargic (even fatalistic) response of governments and peoples to what scientists see as an existential crisis for the planet Earth.

\section{The Chinese paradox}

The case of the People's Republic of China (PRC) is particularly relevant to the issue of global warming. Of all the countries in the world, China has the largest population, the second-largest territory and the second-largest (and fastest-growing) economy. China is also important because it is particularly vulnerable to climate

\footnotetext{
44 Hulme, Why We Disagree, 115-16 and 120-2.

45 ibid., 139-40.

46 See, for example, Paul J. Crutzen, 'Albedo Enhancement by Stratospheric Sulfur Injection: A Contribution to Resolve a Policy Dilemma?', Climatic Change 77, no. 3-4 (August 2006): 211-20, doi.org/10.1007/s10584-0069101-y; Jeff Goodell, How to Cool the Planet: Geoengineering and the Audacious Effort to Fix Earth's Climate (Boston, MA: Houghton Mifflin, 2010); and James Rodger Fleming, Fixing the Sky: The Checkered History of Weather and Climate Control (New York: Columbia University Press, 2010).
} 
change. Only a third of its territory receives enough rain to support agriculture, and that rain comes in the form of monsoons, with the heaviest downpours in the summer. Much of Chinese agriculture depends on capturing and storing rainwater in reservoirs and delivering it to the fields through an intricate network of canals. Historically, the monsoons have supported a dense population, but have also left it vulnerable to unpredictable droughts and floods. No one knows how global warming will affect the monsoons, but it is unlikely to make them more regular and predictable.

Just as worrying is the impact of global warming on snow and ice in the Himalayas and the Tibetan Plateau. The Himalayan and Tibetan glaciers supply much of the meltwater that flows into the Yangtze and Pearl rivers, the basins of which are home to almost a billion people. (They also feed the rivers of Pakistan, India and South East Asia.) If global temperatures were to rise by $1.5^{\circ} \mathrm{C}$ above pre-industrial levels- the most conservative of the scenarios proposed by the IPCC - the average temperature in the high mountains of Asia would rise by $2.1^{\circ} \mathrm{C}$, causing the amount of ice in the Asian glaciers to shrink by $36 \pm 7$ per cent. According to the IPCC's less conservative scenarios, the loss of ice could reach as high as 69 per cent. ${ }^{47}$ As the glaciers melt, the amount of water they release is likely to rise for a few years, then decline. Again, the consequences for China and the rest of Asia are unpredictable.

The Chinese Government is well aware of the dangers of global warming. China's National Climate Change Programme, published in June 2007, recognised that the country's greenhouse gas emissions had quadrupled since 1979, but insisted on giving priority to economic development. Action on climate change, it argued, would rely on improvements in energy efficiency and on the positive effects of the one-child policy, which had prevented 300 million births and thereby avoided 1.2 billion tons of $\mathrm{CO}_{2}$ emissions per year. ${ }^{48}$

Since 2007, the Chinese Government and the Communist Party have become more deeply committed to fighting climate change. Now that the US Government has withdrawn from the Paris Agreement of 2015, the Chinese Government has stepped forward as a leader in this field. At the Paris conference of 2015, it pledged that its greenhouse gas emissions would peak in 2030; by then, 20 per cent of its energy would come from non-fossil fuel sources. ${ }^{49}$ At the Communist Party Congress in October 2017, President Xi Jinping declared that China had taken a 'driving seat

47 P. D. A. Kraaijenbrink et al., 'Impact of a Global Temperature Rise of 1.5 Degrees Celsius on Asia's Glaciers', Nature 549(7671): 257-9, doi.org/10.1038/nature23878; J. Graham Cogley, 'The Future of Asia's Glaciers', Nature 549(7671): 166-7, doi.org/10.1038/549166a.

48 Hulme, Why We Disagree, 271-2.

49 Brad Plumer and Nadja Popovich, 'Tracking the World's Progress in Meeting Its Climate Goals', New York Times, 11 November 2017; Keith Bradsher and Lisa Friedman, 'Forum Lauds Climate Efforts Even as its Emissions Climb', New York Times, 26 January 2018; International Energy Agency, World Energy Outlook 2017: Executive Summary, iea.org, accessed February 2018; Edward Wong, 'Report Faults China’s Pace In Curbing Its Emissions', New York Times, 20 July 2018. 
in international cooperation to respond to climate change'. Later, he announced that the effort to reduce global warming is 'a responsibility we must assume for future generations' ${ }^{50}$

To help reduce greenhouse gas emissions, the PRC has become the world leader in the manufacture of solar panels and wind turbines, and aims to become the leader in the manufacture of electric cars. It has also created a market devoted to trading credits for greenhouse gas emissions from the electric power sector. Yet the Chinese Government's well-meaning statements and its policy of encouraging technological fixes run into major, and perhaps insurmountable, obstacles: the government's desire to stimulate the nation's economic and urban development and the Chinese people's desire for a better (i.e. more energy-intensive) way of life. After all, it is the booming Chinese economy and cities, and the resulting rising standard of living that have given legitimacy to the government and to the Communist Party.

China is a major perpetrator of global warming because its growing economy is so heavily dependent on fossil fuels, especially coal. Currently, China continues to be the world's number one consumer of coal..$^{51}$ As of January 2018, China had 936,057 coal-fired power plants of 30 megawatts or higher, most of them built since $2000 .{ }^{52}$ In 2017, China burned more coal than the rest of the world and emitted nearly as much $\mathrm{CO}_{2}$ as the United States and Europe combined. While $\mathrm{CO}_{2}$ emissions declined in the United States, Britain, Japan and Mexico in 2017, they rose by 1.7 per cent in China, making that country the main contributor to the global increase of 2 per cent that year. ${ }^{53}$

The Chinese Government, concerned about the appalling levels of air pollution in its cities, pledged to reduce coal output by 150 million metric tons in 2018; in some areas, coal-burning stoves have been removed from homes, even before they could be replaced by less polluting stoves burning natural gas. ${ }^{54}$ Over the long run, China's electricity generation is expected to shift increasingly to renewable sources, reducing coal's share from 72 per cent in 2015 to an expected 47 per cent in $2040 .{ }^{55}$ Yet, even while the government has made efforts to reduce coal burning, it has encouraged Chinese companies to construct or finance hundreds of coal-burning power plants

50 Lisa Friedman, 'As U.S. Sheds Role as Climate Change Leader, Who Will Fill the Void?', New York Times, 12 November 2017; Keith Bradsher and Lisa Friedman, 'China Unveils an Ambitious Plan to Curb Climate Change Emissions', New York Times, 19 December 2017, and Bradsher and Friedman, 'Forum Lauds Climate Efforts by China'.

51 'Coal Plants in China' and 'Global Coal Plant Tracker', endcoal.org, accessed March 2018.

52 ibid.

53 Brad Plumer, 'Behind the Increase in Gas Emissions Last Year', New York Times, 23 March 2018; Wong, 'Report Faults China's Pace'.

54 Steven Lee Myers, 'In China's Coal Country, a Ban Brings Blue Skies and Cold Homes', New York Times, 10 February 2018; 'China to Cut More Coal, Steel Output to Defend "Blue Skies", New York Times, 4 March 2018.

55 US Energy Information Administration, Today in Energy (27 September 2017), eia.gov, accessed 8 May 2018. 
in other countries, such as Kenya. ${ }^{56}$ In other words, its concern for air quality in Chinese cities and for global warming is real, but is tempered by its efforts to expand its economic footprint around the world.

The most important cause of the increase in greenhouse gas emissions comes from a phenomenal expansion in electricity generation. From 2006 to 2016, China's electricity generation rose from 4,865.7 to 6,142.5 TWh, an increase of 26.2 per cent, while the United States increased its electricity generation by a mere 0.5 per cent. In 2016, 65.5 per cent of China's electricity came from burning coal, compared to 38.3 per cent for the world as a whole. ${ }^{57}$

Much of that electricity is consumed by cities. China, once a land of small farms, has suddenly become a land of big cities. As of September 2017, China had 663 cities, of which 102 had more than 1 million inhabitants. ${ }^{58}$ By the end of 2016, 57.4 per cent of the Chinese population — some 800 million people-lived in cities. ${ }^{59}$ To keep up with the booming urban population, the cities, some of them brand new, like Shenzhen, have been erecting high-rise apartment buildings by the hundreds. The inhabitants of these new buildings use electricity for lights, lifts and appliances, especially air conditioners.

Constructing these new cities has required enormous amounts of cement. Cement is produced by heating limestone (calcium carbonate) to turn it into lime (calcium oxide or calcium hydroxide), in the process releasing $\mathrm{CO}_{2}$. Sixty per cent of the $\mathrm{CO}_{2}$ emitted by cement plants comes from this chemical reaction and another 40 per cent from the fuel used to generate heat. In the past decade, China has produced over half of the world's cement, with an average annual increase of 2.6 per cent. ${ }^{60}$

Beginning in 1984, a large share of China's cement has gone into the construction of the world's most extensive motorway network. By the end of 2017, China's network, built largely of concrete, had reached 84,456 miles $(136,000 \mathrm{~km})$, including seven motorways radiating from Beijing, plus 11 north-south and 18 east-west motorways. This network is 76 per cent longer than the American interstate highway system, which reached 47,847 miles $(77,048 \mathrm{~km})$ in 2016 . China is also constructing lesser roads and highways at a similarly rapid rate. ${ }^{61}$

\footnotetext{
56 Somini Sengupta, 'Why Build Kenya’s First Coal Plant? Think China', New York Times, 27 February 2018.

57 BP Statistical Review of World Energy June 2017, bp.com, accessed August 2018.

58 'List of cities in China', Wikipedia, accessed February 2018.

59 'Urbanization in China', Wikipedia, accessed February 2018.

60 'Sustained Global Cement Growth Expected', International Cement Review, 21 July 2015.

61 'Expressways of China', Wikipedia, accessed February 2018; US Department of Transportation, Federal Highway Administration, Office of Highway Policy Information, Highway Statistics 2016, Table HM-12: Public Road Length—2016, www.fhwa.dot.gov/policyinformation/statistics/2016/pdf/hm12.pdf, accessed September 2018.
} 
These highways, and the streets that have accompanied China's unprecedented urban growth, were built for China's booming number of automobiles, trucks and buses. In 1960 , China produced only 22,574 motor vehicles, and still only 222,288 in 1980 (not counting two-wheelers). By 2009, production had risen to 13.79 million. In 2016, it reached an extraordinary 28.1 million (29.6 per cent of the world total), more than the United States, Japan and Germany combined. ${ }^{62}$

To be sure, the Chinese motor vehicle industry, encouraged (and subsidised) by the government, is making an effort to produce electric vehicles. As a result, China produces three times more electric vehicles than the United States, and more than the rest of the world. By December 2017, it had produced 1.7 million electric vehicles: 19.9 per cent of them plug-in hybrids and 90.1 per cent full-battery (not counting 200 million electric scooters and motorcycles). By 2040, the government expects that 25 per cent of all motor vehicles will be electric. ${ }^{63}$ But the other 75 per cent will burn gasoline or diesel fuel, and thus emit $\mathrm{CO}_{2}$. And the electric ones will get their electricity from power plants, nearly three-quarters of which burn coal and emit greenhouse gases. ${ }^{64}$

\section{Conclusion}

China represents an extreme example of the dilemma facing all nations. Almost all political leaders have pledged to reduce greenhouse gas emissions in order to keep global warming within reasonable limits. Yet they all desire to grow their countries' economies. These two goals are incompatible, for economic development requires increasing the consumption of fossil fuels, thereby increasing greenhouse gas emissions. Technological innovations that produce energy without emitting greenhouse gases are coming on stream, but much too slowly to achieve the $1.5^{\circ} \mathrm{C}$ or $2^{\circ} \mathrm{C}$ goal pledged at conferences and promised by politicians. The alternativedeliberately slowing down their economic development-is simply unacceptable. In their policy statements, the world's governments (other than the United States) agree with the findings of the scientists. But in their eagerness to stimulate their countries' economic development and satisfy their peoples' desire for a better life, they act as if they agreed with the sceptics. It is this conflict of interest that makes global warming unstoppable.

62 Organisation Internationale des Constructeurs d'Automobiles, 2016 Production Statistics, oica.net, accessed February 2018.

63 International Energy Agency, World Energy Outlook 2017: Executive Summary, iea.org, accessed February 2018.

64 Keith Bradsher, 'China Hastens the World Toward an Electric-Car Future', New York Times, 7 October 2017. 
This text is taken from International Review of Environmental History, Volume 5, Issue 1, 2019, edited by James Beattie, published 2019 by ANU Press, The Australian National University, Canberra, Australia.

doi.org/10.22459/IREH.05.01.2019.04 